\title{
Developing Democracy through Liberal International Law
}

\author{
Russell Buchan*
}

\begin{abstract}
By deploying the concepts of the international society and the international community this article constructs and defends an explanatory framework that enables us to better understand the complex international political and legal structure of the contemporary world order and better explain why violations of international peace and security occur. The international community describes an association of liberal states that has formed within the politically pluralist international society of sovereign states since the end of the Cold War and which considers only those states that exhibit respect for liberal values as legitimate. Moreover, it argues that the international community has demonstrated a tendency to deny non-liberal states their previously held sovereign right to nonintervention and has instituted a global campaign for their liberal reformation. The existence of the international community is evidenced by reference to the practice of liberal states vis-à-vis non-liberal states since the end of the Cold War and particular attention is paid to the reaction of the international community to the overthrow of the democratic regimes in Honduras and the Ivory Coast and the violent suppression of pro-democracy demonstrations in Libya and Syria. In light of these developments, this article assesses the impact of the international community upon international law and suggests that international law is being reformulated in order to construct a liberal international law that allows for the effective promotion of liberal values.
\end{abstract}

\section{Keywords}

Liberalism, International Community, International Society, Arab Spring

\section{Introduction}

'The dominant approach in international relations theory for virtually the past two millennia, from Thucydides to Machiavelli to Morgenthau, has been Realism.' Stated succinctly, the gist of realism is that states exist in a condition of anarchy because there is no overarching international government that is capable of guaranteeing their

* Senior Lecturer in Law, University of Sheffield (UK).

1 Anne-Marie Slaughter, 'International Law in a World of Liberal States' (1995) 6 EJIL 503, 507. 
survival. In this environment, states are by necessity selfish and untrusting actors that are primarily concerned with pursuing material power in order to deter potential aggressors and, where necessary, to repel them. In this realist world state survival, and thus international peace and security more generally, is maintained where there is a balance of material power between states. Where power becomes unbalanced and the system moves towards hegemony, the maintenance of international peace and security becomes susceptible to violation. With its focus upon material power, realism therefore sees little utility in international law and international law is regarded as more or less irrelevant as to whether international peace and security is maintained. ${ }^{2}$

In 2013, I published a monograph that challenged the adequacy of realism as a theoretical framework to explain the political and legal interactions of states in the contemporary world order and to understand why violations of international peace and security occur or, where it is maintained, why this is the case. ${ }^{3}$ This challenge was pursued by constructing a unique explanatory framework that was predicated upon the concepts of the international society and the international community. In short, the argument developed in the monograph was that since the end of the Cold War an international community of liberal states has formed within the politically pluralist international society of sovereign states. Significantly, I argued that this international community demonstrates a tendency to dismiss states that fail to demonstrate respect for liberal values as illegitimate and, perhaps more significantly, to deny them their previously held sovereign right to non-intervention. In fact, I submitted that this international community is engaged in a sustained campaign to promote respect for liberal values to non-liberal states.

The monograph has attracted considerable attention. Whilst there has been praise for the arguments it develops, ${ }^{4}$ others have voiced criticism, ${ }^{5}$ some vociferously. ${ }^{6}$ In particular, these critics challenge the explanatory strength of the concepts of the

2 For a general discussion of realism, see Kenneth Waltz, Theory of International Politics (McGraw-Hill 1979).

3 Russell Buchan, International Law and the Construction of the Liberal Peace (Hart Publishing 2013).

4 International Law and the Construction of the Liberal Peace was the recipient of the 2014 American Society of International Law's Francis Lieber prize for an outstanding monograph in the field of the law of armed conflict. The book has also been positively reviewed by Eric De Brabandere in (2014) 61 NILR 249 and Achilles Skordas in (2015) 64 ICLQ 491. For a positive yet more modest review, see Jean d'Aspremont, 'Democracy and International Law according to Russell Buchan: Prescribing under the Guise of Explaining?' (EJIL: Talk!, 17 November 2014) <http://www.ejiltalk.org/democracy-and-international-lawaccording-to-russell-buchan-prescribing-under-the-guise-of-explaining/> accessed 14 September 2015.

5 Brad Roth, 'International Law's Enemy Within: Buchan's "International Community" as Rival to the Positive Legal Order’ (EJIL: Talk!, 17 November 2014) <http://www.ejiltalk.org/international-laws-enemywithin-buchans-international-community-as-rival-to-the-positive-legal-order/> accessed 14 September 2015; Astri Suhrke, 'From Principle to Practice: US Military Strategy and Protection of Civilians in Afghanistan' (2015) 22 Intl Peacekeeping 202.

6 Gregory Fox, 'A Comment on Russell Buchan's "International Law and the Construction of the Liberal Peace” (EJIL: Talk!, 18 November 2014) <http://www.ejiltalk.org/a-comment-on-russell-buchansinternational-law-and-the-construction-of-the-liberal-peace/> accessed 14 September 2015. 
international society and the international community and thus their utility in explaining the character of international relations, both in their political and legal dimension.

The objective of this article is to engage with and respond to these criticisms. In pursuit of this objective, this article is structured as follows. In section 2, I sketch out the key arguments of the book and, in particular, I elaborate upon the concepts that I refer to as the international society and the international community. In section 2, I also outline the main criticisms that have been levied against this explanatory framework and attempt to rebut them. In rebutting these criticisms, I examine events that have occurred subsequent to the publication of the book and argue that these developments add additional weight to my thesis that through the activities of the international community the promotion of liberal values has now become embedded in international practice. Sections 3 and 4 discuss the international community's reaction to the overthrow of democracy in Honduras and the Ivory Coast, respectively. In section 5, I examine the international community's response to the Arab Spring and, in particular, I focus on events in Libya and Syria. In section 6, my attention turns to the role of international law in the international society and the international community. I examine how the content and character of international law is affected by these two opposing associations and the normative contestation that exists between them. In a nutshell, I argue that the international community has instigated a liberal international law to which the raison dêtre is the promotion of liberal democracy to non-liberal states.

\section{The international society and the international community}

The concepts of the international society and the international community are central to the explanatory framework that I develop. I argue that when confronted with the global devastation wrought by the Second World War states recognised that they embraced a common interest in forging an international environment where their political independence and territorial integrity (that is, their sovereignty) could be protected and international peace and security maintained, and that this was best achieved through the implementation of a comprehensive international legal framework. What emerged in the years following the end of the Second World War, I submit, was an international society of states that was constituted by a universally accepted international legal rule that regarded all states qua states as sovereign equals. ${ }^{7}$ Thus, provided a political community is a state under international law, it is regarded as sovereign and so legally entitled to determine its internal affairs to the exclusion of all others.

In terms of determining membership of this international society, and more crucially who is entitled to sovereignty as a product of this membership, the definition of statehood is all important. As we know, a political community is a state under international law where it exhibits a permanent population, a defined territory, an effective government

7 See Robert H Jackson, The Global Covenant: Human Conduct in a World of States (OUP 2000). 
and the capacity to enter legal relations. ${ }^{8}$ Significantly, the requirement of an effective government refers to a government's effective physical control over the population within that territory; this criterion makes no reference and requires no normative judgement as to the quality of the control that the government imposes. What this means is that all states, regardless of whether the government in effective control of that state is fascist, communist, democratic or autocratic, are legitimate members of this international society and cast as sovereign equals.

Importantly, in order to formalise and ultimately strengthen its association, the international society created the United Nations (UN). In this sense, the UN emerged as the institutional representation of the international society and, at least until the end of the Cold War, was dedicated to protecting the sovereign equality of its member states. ${ }^{9}$ Organs of this organisation such as the Security Council and General Assembly were therefore intended to act as guardians of state sovereignty and, more broadly, international peace and security. ${ }^{10}$

Given that membership of the international society is conferred automatically upon achievement of statehood, all states are legitimate members of the international society, and thus this society confers universal membership. I submit, however, that the end of the Cold War represented a seminal moment in the trajectory of international relations, and that since this date the political and legal structure of the world order cannot be adequately captured by the concept of the international society alone.

The end of the Cold War is such a significant date because it was at this time that liberal states began seriously to assess the performance of the international society (and the international legal framework it represents) in achieving its overarching goal of protecting state sovereignty from external intervention and thereby maintaining international peace and security. Significantly, for liberal states this empirical assessment revealed a failing of the international society and the legal regime it imposes to eliminate not just intervention in state sovereignty but in particular armed intervention, which is undoubtedly the most pernicious form of intervention. ${ }^{11}$ However, although international legal rules were considered generally ineffective in maintaining international peace and security, for liberal states all was not lost because 'there nevertheless exists an island of peace in an ocean of conflicts and wars. ${ }^{12}$

8 Convention on the Rights and Duties of States (adopted 26 December 1933, entered into force 26 December 1934) 165 LNTS 19, art 1.

9 See Charter of the United Nations (adopted 26 June 1945, entered into force 24 October 1945) 1 UNTS 16, arts 2(1), 2(4), 2(7) (UN Charter).

10 ibid arts 2(1), 2(7), 39. See generally Frederic Kirgis, 'The Security Council's First 50 Years' (1995) 89 AJIL 506.

11 In 1970, Franck argued that art 2(4) had been violated so frequently that it 'mocks us from the grave': Thomas Franck, 'Who Killed Article 2(4)? or: Changing Norms Governing the Use of Force by States' (1970) 64 AJIL 809, 809.

12 Thomas Risse-Kappen, 'Democratic Peace-Warlike Democracies? A Social Constructivist Interpretation of the Liberal Argument' (1995) 1 Eur J Intl Relations 491, 492. 
I argue that liberal states subscribe to the empirical 'fact' ${ }^{13}$ that notwithstanding the continual inter-state violence experienced within the international society, liberal states enjoy a stable peace where any disputes that have emerged between them have been resolved without recourse to violence. ${ }^{14}$ That liberal states have managed to forge a zone of peace is most often explained on the basis of the normative structure of liberal states. The argument runs that at the heart of a liberal state is the belief 'that individuals everywhere are fundamentally the same, and are best off pursuing self-preservation and material well-being. Freedom is required for these pursuits, and peace is required for freedom; coercion and violence are counter-productive. ${ }^{15}$

If freedom is to be preserved, violence as a form of political adjudication must be forgone at all costs. As a result, '[m] odern democratic societies foster the internalization of norms for regulating and reconciling competing interests and values in public affairs in ways that are neither violent nor coercive. ${ }^{16}$ The consequence is that if the norms regulating the decision-making processes in a democratic system are orientated toward non-violence and the peaceful resolution of political conflicts, one could expect that democracies externalise these norms when dealing with one another. ${ }^{17}$ If a norm exists that requires the peaceful resolution of disputes within two states, it will also require the peaceful resolution of disputes between them. ${ }^{18}$ Thus, when two liberal states come into contact in the international sphere and, after observation and scrutiny of each other's political constitution, perceive each other to be genuinely liberal a mutual trust of peaceful exchange will be established.

Motivated by the liberal peace thesis, ${ }^{19} \mathrm{I}$ argue that liberal states have formed a cohesive international community that exists within the international society and which

13 Bruce Russett, 'The Fact of Democratic Peace' in Michael E Brown, Sean M Lynn-Jones and Steven E Miller (eds), Debating the Democratic Peace (MIT Press 1996) 58, 59.

14 Much empirical research is available to substantiate the claim that liberal states have always enjoyed peaceful relations. Levy explains that the practical absence of war between liberal states is 'the closest thing we have to an empirical law in the study of international relations': Jack S Levy, 'Domestic Politics and War' in Robert I Rotberg and Theodore K Rabb (eds), The Origin and Prevention of Major Wars (CUP 1989) $79,88$.

15 John M Owen, 'How Liberalism Produces Peace' in Michael E Brown, Sean M Lynn-Jones and Steven E Miller (eds), Debating the Democratic Peace (MIT Press 1996) 116, 118.

16 William J Dixon, 'Democracy and the Peaceful Settlement of International Conflict' (1994) 88 APSR 14, 16.

17 Risse-Kappen (n 12) 500.

18 '[Thus] the culture, perceptions and practices that permit compromise and the peaceful resolution of conflicts without the threat of violence within countries come to apply across national boundaries toward other democratic countries': Dixon (n 16) 15-18.

19 The liberal peace thesis has become firmly embedded in the political rhetoric of liberal states. In 1994, US President Bill Clinton explained 'democracies do not attack each other': Bill Clinton, 'Confronting the Challenges of a Broader World' (US Department of State Dispatch, 27 September 1993) <http://dosfan.lib. uic.edu/ERC/briefing/dispatch/1993/html/Dispatchv4no39.html> accessed 28 September 2015. In 2006, for example, US President George Bush declared that 'democracies yield the peace we all want. History has taught us democracies don't war. (...) Democracies yield peace': George W Bush, 'President Thanks US and Coalition Troops in Afghanistan' (US Department of State Archive, 1 March 2006) <http://georgewbushwhitehouse.archives.gov/news/releases/2006/03/20060301-3.html> accessed 28 September 2015. 
considers only those states that demonstrate respect for the liberal values of democracy, human rights and the rule of law as legitimate. ${ }^{20}$ Note that liberal states of the international community do not forfeit their membership of the international society. As states, liberal states continue to enjoy membership of the international society. However, they now possess additional, overriding membership of the international community and subscribe to its normative framework and agenda. Importantly, the international community has sought to reserve sovereignty (and the protection it affords) for liberal, legitimate states only. Non-liberal states have therefore been increasingly denied their previously held sovereign right to determine their own internal political configuration and the international community has engaged in an often aggressive campaign for their liberal reformation. In particular, liberal states have sought to exploit their growing influence within the world order in order to cajole international organisations, and especially the UN Security Council because of its mandatory powers, into taking decisions that facilitate the promotion of liberal values. ${ }^{21}$

As I have already noted, my use of the concept of the international community as an explanatory tool has come under criticism since the publication of my book. In their reviews of my thesis Professors Greg Fox and Brad Roth, scholars who have been pioneers in assessing the role of international law in democracy promotion, ${ }^{22}$ have made it clear that they consider the bright lines I draw between the international society and the international community to be far murkier in reality, and that the political structure of the contemporary world order is far more complex and nuanced than I portray. In particular, Fox and Roth argue that there are many instances in the postCold War era where liberal states have failed to dismiss non-liberal states as illegitimate and, in fact, have enjoyed close relationships with them. Their argument is that discrete national interests of liberal states are sufficiently prominent to prevent them from transforming their grand political rhetoric relating to the normative supremacy of liberal democracy into practice, such as the desire to preserve beneficial economic or security arrangements. In light of this, Roth explains that my understanding of the international community is overly 'bold' and 'straightforward' and which pictures the scene far 'too starkly'. Ultimately, Roth concludes that the account I offer is 'premature' and needs to

20 It is not the objective of this article to identify which states can be regarded as liberal and therefore members of the international community. This being said, Freedom House publishes annually a list of 'free' states within the world order and Freedom House's understanding of which states are 'free' broadly aligns with my understanding of which states are liberal: Freedom House, '2015 Freedom in the World' (2015) <https://freedomhouse.org/report-types/freedom-world\#.VeGZnGC4nfY> accessed 14 September 2015.

21 Numerous examples are available. See, eg, the Security Council's use of its Chapter VII powers to restore the democratically elected President to power in Haiti (UNSC Res 940 (31 July 1994) UN Doc S/RES/940) and its use of Chapter VII to authorise the liberal reconstructions of Kosovo (UNSC Res 1244 (10 June 1999) UN Doc S/RES/1244) and East Timor (UNSC Res 1272 (25 October 1999) UN Doc S/RES/1272). More recently, the Security Council authorised the use of 'all necessary means' under Chapter VII to protect civilians in Libya (UNSC Res 1973 (17 March 2011) UN Doc S/RES/1973).

22 See, eg, Gregory Fox and Brad Roth, Democratic Governance and International Law (CUP 1999). 
be more 'moderate' in order to be convincing. Fox makes a similar point when he labels the framework I develop 'reductionist.' ${ }^{23}$

To a certain extent I accept this criticism. It is correct that in the post-Cold War era there are examples of liberal states engaging with non-liberal states in such a manner as to indicate that they are tolerant of their non-liberal ideology. The argument is that where the maintenance of cordial relations is beneficial to liberal states (perhaps for economic reasons such as maintaining or improving trade relations or for security reasons such as deterring and suppressing international terrorism), liberal states are prepared to recognise non-liberal regimes as legitimate. Roth identifies the example of liberal states having 'recently embraced non-liberal solutions' in Egypt on the basis that it is 'convenient to other agendas. ${ }^{24}$ Another recent and prominent example would be the international community's seemingly close relationship with Saudi Arabia, which is clearly not a liberal state. In the words of the government of the United Kingdom (UK):

We develop and maintain the long-standing relationship between the UK and Saudi Arabia. We build on the bilateral relationship between our two governments and peoples, especially in the areas of trade and investment, education, culture, energy and climate security, and defence. $^{25}$

It goes without saying that the social realities of the institution of recognition within the international community are complex and can take different meanings within a particular context. I therefore accept that factors other than a state's political constitution can influence the way in which it is perceived by liberal states. However, my objective is not to construct an explanatory framework that accounts for every micro-aspect of international social reality. If it were, then my project would essentially be a restatement of a mass of raw data. This may make for a robust research project in descriptive or explanatory terms. Ultimately, however, it would be unimpressive analytically because it would fail to judge what data is significant causally to the world order and that which is less relevant. In addition, and significantly, it would also fail to identify what I still believe to be a convincing line of explanation: namely, that since 1990 liberal states have exhibited consistent trends and patterns of conduct in their interactions with non-liberal states. Thus, it is not my objective to provide an all-encompassing 'theory of everything' which can explain international relations in their entirety since 1945 or even 1990. Instead, my objective is to identify salient empirical data and, on this basis, propose an explanatory framework that utilises ideal-types like the international society and the international community to elucidate generic transformations to the structural and normative configuration of the world order.

23 Roth (n 5); Fox (n 6).

24 Roth (n 5).

25 UK Foreign and Commonwealth Office, 'UK and Saudi Arabia' (2015) <https://www.gov.uk/government/ world/saudi-arabia> accessed 14 September 2015. See generally John Wight, 'Britain's Relationship with Saudi Arabia is a Disgrace' The Huffington Post (14 March 2015) <http://www.huffingtonpost.co.uk/johnwight/saudi-arabia-britain_b_6451044.html> accessed 14 September 2015. 
Of course my claim is an empirical one; that liberal states have cohered into an international community which exhibits a tendency to dismiss non-liberal states as illegitimate and take reformative action against them. It is therefore essential that I am able to draw upon a sufficient amount of empirical evidence to substantiate my claim.

Propelled by the hype and hubris of the Bush and Blair administrations there is much practice during the 1990s to support the existence of this international community of liberal states. At a glance, obvious examples would be: the intervention in Haiti in response to the overthrow of the democratically elected President; ${ }^{26}$ the use of military force by the North Atlantic Treaty Organization (NATO) in Kosovo to end the egregious human rights abuses; and the liberal reconstructions of Kosovo and East Timor. ${ }^{27}$ Indeed, during the mid-to-late 1990s, a considerable amount of academic literature was published which documented the preparedness of liberal states to dismiss non-liberal states as illegitimate and, where necessary, to intervene in their internal affairs in order to promote respect for liberal values. The likes of Michael Reisman, Thomas Franck and Jean d'Aspremont were key protagonists in this literature. ${ }^{28}$ However, in terms of defending the existence of the international community, the more significant date is 11 September 2001. The reason for this is because in the wake of the devastating $9 / 11$ terrorist attacks previously seminal proponents of the international community doctrine started to reject this thesis, and instead assert that in their foreign policy leading states within the international community have exhibited a return to realist ideology. These commentators now argue that because of the likes of international terrorism, the global economic downturn and the emerging multipolar world, the nature of the international environment has changed-or at least had become more complex-and that liberal states are no longer (as) concerned with the promotion of liberal values but instead (more) preoccupied with protecting discrete national security interests such as their security and economic prosperity. Consider the following remarks by d'Aspremont:

Contemporary practice shows signs of a return to realist and non-ideological foreign policies, threatening the centrality of democracy promotion in the foreign policies of most democratic states. $^{29}$

The battle lines over whether the doctrine of the international community remains a convincing tool to explain the nature of international relations are therefore drawn in the post $9 / 11$ era. For this reason, I will identify and analyse post-9/11 examples of the international community dismissing governments as illegitimate on the basis of their non-liberal credentials and, where necessary, intervening in such states in order

26 UNSC Res 940 (31 July 1994) UN Doc S/RES/940.

27 See UNSC Res 1244 (10 June 1999) UN Doc S/RES/1244; UNSC Res 1272 (25 October 1999) UN Doc S/ $\mathrm{RES} / 1272$.

28 W Michael Reisman, 'Sovereignty and Human Rights in Contemporary International Law' (1990) 84 AJIL 866; Thomas Franck, 'The Emerging Right to Democratic Governance' (1992) 86 AJIL 46; Jean d'Aspremont, 'Legitimacy of Governments in the Age of Democracy' (2006) 38 NY J Intl L \& Politics 877.

29 Jean d'Aspremont, 'The Rise and Fall of Democracy Governance in International Law: A Reply to Susan Marks' (2011) 22 EJIL 549, 551. 
to protect and promote respect for liberal values. Particular emphasis will be given to examples that were developing as I was writing the book and examples that have developed subsequently.

\section{Honduras}

A good illustration of the role of the international community engaging in a normative assessment of the political credentials of a state is in relation to the events that began to unfold in Honduras in 2009. In 2009, the democratically elected President of Honduras, Manuel Zelaya, attempted to initiate constitutional reform by holding a non-binding referendum. The Supreme Court of Honduras adopted what was regarded as a legally binding decision that required this poll to be cancelled. ${ }^{30}$ Zelaya refused to heed the Supreme Court's decision and the Honduran Supreme Court issued a warrant for his arrest. Importantly, it is widely accepted that the Supreme Court did not have the authority to issue such a warrant under the constitution. ${ }^{31}$ Acting on this order, during the night of 28 June 2009, the Honduran army stormed the presidential home and detained Zelaya. Rather than bringing him to trial as the arrest warrant required, the soldiers forced him onto a plane to Costa Rica. Later that day, after receiving a letter of resignation from Zelaya (although Zelaya protested that the letter was fabricated), the Supreme Court voted to remove him from office and appointed his successor. ${ }^{32}$

In the days and weeks following his exile there was widespread condemnation of the events that had occurred. The UN General Assembly adopted a resolution unambiguously stating that Zelaya was the legitimate President of Honduras because of his democratic credentials and that he must be returned expeditiously to power. ${ }^{33}$ The General Assembly condemned

the coup d'état in the Republic of Honduras that has interrupted the democratic and constitutional order and the legitimate exercise of power in Honduras, and resulted in the removal of the democratically elected President of that country, Mr. José Manuel Zelaya Rosales [and demanded] the immediate and unconditional restoration of the legitimate and Constitutional Government of the President of the Republic of Honduras, Mr. José Manuel Zelaya Rosales, and of the legally constituted authority in Honduras, so that he may fulfil the mandate for which he was democratically elected by the Honduran people. ${ }^{34}$

30 Supreme Court of Honduras Communiqué, 9 July 2009; Doug Cassel, 'Honduras: Coup d'Etat in Constitutional Clothing?' (2009) 13 ASIL Insights 9 <http://www.asil.org/insights/volume/13/issue/9/ honduras-coup-d\%E2\%80\%99etat-constitutional-clothing > accessed 14 September 2015.

31 The President was 'forced out of the country in breach of the Constitution. Zelaya was formally deposed by a Congress with no clear constitutional power to remove him in the circumstances at hand, let alone summarily, without so much as a hint of due process of law. This was indeed a coup d'etat': Cassel (n 30).

32 William Booth and Juan Forero, 'Honduran Military Sends President into Exile; Supportive Congress Names Successor' The Washington Post (29 June 2009) <http://www.washingtonpost.com/wp-dyn/content/ article/2009/06/28/AR2009062800635.html> accessed 14 September 2015.

33 UNGA Res 63/301 (30 June 2009) UN Doc A/Res/63/301.

34 ibid paras $1-2$. 
Similarly, the Organization of American States (OAS) condemned the President's removal as illegitimate and unlawful. ${ }^{35}$ Furthermore, the OAS invoked for the first time article 21 of the Inter-American Democratic Charter, which enabled the OAS to suspend Honduras from the organisation. ${ }^{36}$ In particular, the OAS was clear that its suspension of Honduras's membership was on the basis of the unconstitutional interruption of the democratic order. Interestingly, anticipating suspension, the Honduran regime sought to unilaterally withdraw from the OAS. However, as the OAS Assistant Secretary-General Albert Ramdin explained that ' $\mathrm{t}$ ] he current regime is not recognised as the legitimate government of Honduras; and so only a legitimate government can withdraw from the organization. ${ }^{37}$ Honduras's attempt to withdraw from the OAS was therefore considered void and Honduras was duly suspended. ${ }^{38}$

Many other states in the region unilaterally declared that there had been an unconstitutional overthrow of the democratically elected President, ${ }^{39}$ as did the InterAmerican Commission on Human Rights. ${ }^{40}$ The statement by the President Barack Obama is particularly interesting:

All of us have great concerns about what's taken place there. President Zelaya was democratically elected. He had not yet completed his term. We believe that the coup was not legal and that President Zelaya remains the President of Honduras, the democratically elected President there. In that we have joined all the countries in the region, including Colombia and the Organization of American States.

I think (...) it would be a terrible precedent if we start moving backwards into the era in which we are seeing military coups as a means of political transition rather than democratic elections. The region has made enormous progress over the last 20 years in establishing democratic traditions in Central America and Latin America. We don't want to go back to a dark past. The United States has not always stood as it should with some of these fledgling democracies, but over the last several years, I think both Republicans and Democrats in the United States have recognized that we always want to stand with democracy, even if the results don't always mean that the leaders of those countries are favorable towards the United States. And that is a tradition that we want to continue. ${ }^{41}$

35 OAS General Assembly Res AG/RES 1 (XXXVIII-E/09) (30 September 2009).

36 OAS General Assembly Res AG/RES 2 (XXXVII-E/09) (4 July 2009).

37 Quoted by Ginger Thompson and Marc Lacey, 'OAS Votes to Suspend Honduras Over Coup' New York Times (4 July 2009) <http://www.nytimes.com/2009/07/05/world/americas/05honduras.html?_r=0> accessed 14 September 2015.

38 In justifying the decision of the OAS, the Brazilian Foreign Minister explained, 'If the OAS doesn't work to give guarantees to a democratically elected government, in the case of a coup like this, then what is it for?': quoted by Elizabeth Malkin, 'Ousted Leader Returns to Honduras' New York Times (21 September 2009) <http://www. nytimes.com/2009/09/22/world/americas/22honduras.html?_r=0> accessed 14 September 2015.

39 See Booth and Forero (n 32).

40 Inter-American Court of Human Rights, 'IACHR Strongly Condemns Coup in Honduras' (Press Release 42/09, 28 June 2009) <http://www.cidh.org/Comunicados/English/2009/42-09eng.htm> accessed 14 September 2015.

41 The White House Office of the Press Secretary, 'Remarks by President Obama and President Uribe of Colombia' (29 June 2009) <https://www.whitehouse.gov/the-press-office/remarks-president-obama-andpresident-uribe-colombia-joint-press-availability> accessed 14 September 2015. 
The reason this statement is so interesting is because President Obama clearly recognises that during the Cold War the policy of the international society was to remain agnostic to events internal to a state and it was for the state to decide its own political future, even if this meant violently through a military coup. President Obama explains however that 'over the past several years' the political climate is different and that the violent displacement of a president appointed by the people through free and fair elections is no longer acceptable. Accordingly, the United States (US) suspended military and intergovernmental development aid to Honduras. ${ }^{42}$ Eventually, fresh elections were held and a new president was elected, bringing some much needed political stability within Honduras and substantially easing relations between Honduras and the international community.

\section{Ivory Coast}

Another recent and interesting example of the international community condemning the overthrow of a democratically elected government and refusing to recognise the incumbent government is in the Ivory Coast. Since the civil war in 2002 instability and ethnic tensions dominated the political landscape in the Ivory Coast. As violence between the rebel-held Muslim north and the government-controlled Christian south intensified, in February 2004, the UN Security Council engaged its Chapter VII powers and deployed a peacekeeping mission (known as UNOCI) to establish a 'zone of confidence' that essentially divided the warring communities of the north and the south. ${ }^{43}$ As the violence eased, in 2005 the Security Council extended the mandate of UNOCI to support the organisation of 'open, free, fair, and transparent elections. ${ }^{44}$

On 28 November 2010, the second round of presidential elections was held and, on 2 December 2010, the Independent Electoral Commission announced that Alassane Ouattara had won the election with 54 per cent of the vote. ${ }^{45}$ That Ouattara had won the election was also confirmed by UNOCI. ${ }^{46}$ Against the backdrop of profound ethnic tensions, Ouattara's main opponent in the election, Laurent Gbagbo, claimed that the election had been rigged and the President of the Constitutional Council declared Gbagbo the winner. ${ }^{47}$

42 US Department of State, 'Question Taken at the July 6 Daily Press Briefing' (Office of the Spokesman, 7 July 2009) <http://www.state.gov/r/pa/prs/dpb/2009/july/125757.htm> accessed 14 September 2015.

43 UNSC Res 1528 (27 February 2004) UN Doc S/RES/1528, para 6; UNSC Res 1609 (24 June 2005) UN Doc S/RES/1609, para 2(a).

44 UNSC Res 1609 (24 June 2005) UN Doc S/RES/1609, para 2(q).

45 'Ivory Coast Election: Alassane Ouattara "Beats Gbagbo"' BBC News (2 December 2010) <http://www.bbc. co.uk/news/world-africa-11903470> accessed 14 September 2015.

46 Choi Young-Jin, Special Representative of the Secretary-General and Head of UNOCI, 'Statement on the Certification of the Result of the Second Round of the Presidential Election Held on 28 November 2010' (Abidjan, 3 December 2010) <http://www.un.org/en/peacekeeping/missions/unoci/documents/unoci_ srsg_certification_en_03122010.pdf> accessed 18 September 2015.

47 'Ivory Coast Election' (n 45). 
The international community swiftly endorsed the decision of the Electoral Commission and confirmed Ouattara as the legitimate President of the Ivory Coast. For example, on 7 December 2010, the Economic Community of West African States (ECOWAS) called upon Gbagbo to abide by the election results 'and to yield power without delay. ${ }^{48}$ ECOWAS subsequently suspended the Ivory Coast's participation in the organisation 'until further notice. ${ }^{49}$ On 9 December 2010, the African Union (AU), which usually defers to sub-regional bodies regarding events in its jurisdiction, endorsed the decision of ECOWAS and suspended participation of the Ivory Coast in all AU activities, until such a time [as] the democratically-elected President effectively assumes State power. ${ }^{50}$ In December 2010 and January 2011, ECOWAS twice sent delegations to Gbagbo to urge him to step down voluntarily or be forced from power by military means. ${ }^{51}$

On 20 December 2010, the UN Security Council urged 'all the Ivorian parties and stakeholders to respect the will of the people and the outcome of the election in view of ECOWAS and African Union's recognition of Alassane Ouattara as President-elect of Côte d'Ivoire and representative of the freely expressed voice of the Ivorian people as proclaimed by the Independent Electoral Commission. ${ }^{52}$

This was followed, on 23 December 2010, by a resolution of UN General Assembly which approved (by consensus) the 22 December decision in the Report of the Credentials Committee to accept Ouattara as the legitimate representative of the Ivory Coast, and thereby rescind the credentials of Gbagbo's UN representatives. ${ }^{53}$ On 24 December, the UN Secretary-General released a statement hailing the General Assembly's confirmation of Ouattara's credentials, which he said 'reflects the united position of the international community with respect to the legitimacy of the new government led by President Ouattara. $^{54}$

On 29 December, the European Union (EU) adopted a similar position, endorsing the General Assembly's approval of Ouattara's credentials and declaring that only

48 ECOWAS, 'Final Communiqué on the Extraordinary Session of the Authority of Heads of State and Government on Côte d'Ivoire' (No 188/2010, 7 December 2010) para 9 <http://news.ecowas.int/presseshow. php?nb=188\&lang=en\&annee=2010> accessed 29 December 2015.

49 ibid.

50 AU Peace and Security Department, 'Communiqué of the 252nd Meeting of the Peace and Security Council, adopted following Decision on the Situation in Côte d'Ivoire' (PSC/PR/COMM.2(CCLII) 9 December 2010 ) <http://www.peaceau.org/uploads/communiquy-of-the-252nd.pdf> accessed 29 December 2015.

51 'Kenya PM Says Ivory Coast's Gbagbo should be Forcibly Removed' The New Age (17 December 2010) <http://thenewage.co.za/6059-1020-53-Kenya_PM_says_Gbagbo_should_be_forcibly_removed> accessed 14 September 2015.

52 UN Meetings Coverage and Press Releases, 'Security Council Extends Mission in Cote d'Ivoire until 30 June 2011, Strongly Condemns Attempts to Usurp Will of People, Urges Respect for Election Outcome’ (Press Release SC/10132, 20 December 2010) <http://www.un.org/press/en/2010/sc10132.doc.htm> accessed 18 September 2015. See also UNSC Res 1962 (20 December 2010) UN Doc S/RES/1962.

53 UNGA Res 65/237 (23 December 2010) UN Doc A/RES/65/237.

54 Statement Attributable to the Spokesperson for the Secretary-General on the Credentials of the Representatives of the Côte d'Ivoire Government (New York, 24 December 2010) <http://www.un.org/sg/ statements/?nid=5013> accessed 18 September 2015. 
ambassadors named by Ouattara would be accepted by the EU and its Member States. ${ }^{55}$ Significantly, in addition to this refusal to recognise Gbagbo as President, the EU imposed a host of sanctions against his regime, primarily in the form of travel bans and asset freezes. For example, on 22 December 2010, the Council of the EU adopted a decision imposing a visa ban 'on former president Laurent Gbagbo and 18 other individuals. ${ }^{56}$ On 31 December, this ban was extended to a further 59 'persons who are obstructing the peace process on Cote d'Ivoire and are jeopardising the proper outcome of the electoral process. ${ }^{57}$ On 14 January 2011, the Council imposed an asset freeze on ' 85 individuals that refuse to place themselves under the authority of the democratically elected president, as well as of 11 entities that are supporting the illegitimate administration of Laurent Gbagbo. ${ }^{58}$

Notwithstanding international condemnation, Gbagbo refused to relinquish power and violence spread across the country. In March 2011, in the face of worsening violence, forces loyal to Ouattara took the initiative and marched north to Abidjan, where Gbagbo's support was concentrated. At the same time, UN forces remained active in the Ivory Coast and were provided with a fresh mandate. The Security Council adopted Resolution 1975 on 30 March 2011, which recognised Ouattara as President and demanded an end to the violence. Moreover, it entitled UNOCI to use 'all necessary means' to protect civilians from imminent threat of attack. This resolution also authorised French forces stationed in the Ivory Coast to support UNOCI. ${ }^{59}$ There was controversy as UN forces began using military force directly against Gbagbo's forces. Gbagbo claimed that UN forces were exceeding their mandate and using force with the objective of implementing regime change, although the UN Secretary-General claimed that UN forces only used military force where it was necessary to protect civilians from attack and for the purpose

55 'France says EU Recognizes only Ouattara's Ambassadors' Reuters (29 December 2010) <http://www.reuters. com/article/2010/12/29/us-ivorycoast-diplomacy-idUSTRE6BS1SC20101229> accessed 18 September 2015. Certain EU Member States went further and unilaterally declared their support for Ouattara and explained that they would only accept ambassadors acting under his authority. For example, the UK Foreign and Commonwealth Office explained that the UK 'does not accept the validity of statements made by others': 'Ivory Coast: Gbagbo "Expels UK and Canada Envoys"” BBC News (7 January 2011) <http:// www.bbc.co.uk/news/mobile/world-africa-12132835> accessed 28 September 2015. See also the statement of Canada, which declared that 'Canada does not recognize Laurent Gbagbo's claim to government. As such his request is illegitimate. We will continue to urge Laurent Gbagbo to cede power to President Ouattara who has been recognized internationally as the legitimate President of Cote d'Ivoire following the November 28 elections': 'Britain, Canada Reject Gbagbo's Authority on Envoys' CNN (7 January 2011) <http://edition.cnn.com/2011/WORLD/africa/01/06/ivory.coast.britain/> accessed 28 September 2015.

56 Council of the EU, 'Cote d'Ivoire: Council Adopts Visa Ban List' (Press Release 18206/10, Brussels, 22 December 2010) <europa.eu/rapid/press-release_PRES-10-357_en.pdf> accessed 18 September 2015.

57 ibid.

58 Council of the EU, 'Cote d'Ivoire: Council Adopts Assets Freeze and Designates Additional Persons and Entities Subject to Restrictive Measures' (Press Release 5361/11, Brussels, 14 January 2011) <https://www. consilium.europa.eu/uedocs/cms_data/docs/pressdata/EN/foraff/118854.pdf> accessed 18 September 2015.

59 UNSC Res 1975 (30 March 2011) UN Doc S/RES/1975, para 7. 
of self-defence. ${ }^{60}$ Gbagbo was eventually defeated and arrested on 11 April 2011, effectively bringing the crisis to an end.

\section{The Arab Spring}

My attention will now turn to the reaction of the international community to the Arab Spring, the name given to the democratic uprising that originated in Tunisia in December 2010 and which quickly swept across North Africa and the Middle East, in particular affecting Egypt, Libya, Syria, Yemen, Bahrain, Saudi Arabia and Jordan. I will focus in particular upon the reaction of the international community to the events in Libya and Syria because, in addition to space and time constraints, it was in these states that pro-democracy demonstrations were at their most intense and where the incumbent regimes reacted most violently in their attempt to suppress them. As we shall see, these events provoked a considerable international reaction from the international community in favour of human rights protection.

Within my broader thesis the events in Libya and Syria are of particular importance because, unlike in Honduras and the Ivory Coast where internationally verified elected governments had been prevented from exercising authority, in Libya and Syria there was no elected government that had been deposed from power. Instead, on the basis of the government's lack of liberal credentials these governments were de-recognised and entities that were considered to be broadly representative of the people, and which had promised to implement democratic reform, were instead recognised and accorded legitimacy. In light of this, I submit that the presence of the international community and its impact upon international relations becomes particularly apparent.

\subsection{Libya}

In Libya, Colonel Muammar Gaddafi had been in power for over 41 years when he was faced with mass pro-democracy demonstrations. Gaddafi's regime refused to stand down, fiercely resisted democratic reform and engaged in a prolonged and bloody campaign against those that were considered hostile to the government. As the violence intensified and human rights abuses became severe and widespread (and with war crimes and crimes against humanity being reported), ${ }^{61}$ the international community determined that Gaddafi had lost legitimacy and could no longer be regarded as the legitimate representative of the Libyan people. Moreover, the international community recognised the Libyan National Transitional Council (NTC) as the legitimate government of Libya on the basis that its composition was representative of the people of Libya and because

60 Barbara Plett, 'Did UN Forces Take Sides in Ivory Coast?' BBC News (7 April 2011) <http://www.bbc.com/ news/world-africa-13004462> accessed 14 September 2015.

61 'Libya Conflict: UN Accuses Both Sides of War Crimes' BBC News (1 June 2011) <http://www.bbc.com/ news/world-africa-13622965> accessed 14 September 2015. 
it promised 'to guide the country to free elections. ${ }^{62}$ For example, then US Secretary of State Hilary Clinton declared:

The United States views the Gadhafi regime as no longer having any legitimate authority in Libya. (...) And so I am announcing today that, until an interim authority is in place, the United States will recognize the NTC as the legitimate governing authority for Libya, and we will deal with it on that basis. ${ }^{63}$

Importantly, on 15 July 2011, a Contact Group of 32 states, including leading members of the international community, such as the US and UK, and seven international organisations (including the UN, EU and NATO), banded together and released a joint statement determining:

The Contact Group reaffirmed that the Qaddafi regime no longer has any legitimate authority in Libya and that Qaddafi and certain members of his family must go. Henceforth and until an interim authority is in place, participants agreed to deal with the National Transitional Council (NTC) as the legitimate governing authority in Libya. ${ }^{64}$

Perhaps more significantly, as the human rights situation in Libya deteriorated, the Security Council adopted Resolution 1970 (2011) under Chapter VII of the UN Charter, demanding 'an immediate end to the violence' and called 'for steps to fulfil the legitimate demands of the population'. In addition, Resolution 1970 referred the situation in Libya to the International Criminal Court (ICC). ${ }^{65}$

In April 2011, the UN Security Council, faced with evidence that there was a real threat of a civilian massacre in Benghazi (not least because of Gaddafi's declaration that he would show 'no mercy' to anti-government supporters), ${ }^{66}$ and at the encouragement of the international community, adopted Resolution 1973 which authorised the use of 'all necessary means' to protect civilians from the violence in Libya, subject to the caveat that there could be no deployment of forces into the territory of Libya. ${ }^{67}$ What this meant was that NATO forces, which sought to implement the Security Council's resolution, were limited to conducting military strikes from the sea and air. As the air and sea campaign progressed, many protested that NATO forces were exceeding their mandate by conducting military strikes against Gaddafi forces even though they posed

62 Quoted in 'Q\&A Libyan National Council' BBC News (10 March 2011) <http://www.bbc.com/news/worldafrica-12699785> accessed 14 September 2015. On the recognition of the NTC, see Patrick Capps, 'British Policy and the Recognition of Governments' [2014] PL 229.

63 'US Recognises Libyan Rebel TNC as Legitimate Authority' BBC News (15 July 2011) <http://www.bbc. co.uk/news/world-africa-14164517> accessed 14 September 2015.

64 'Fourth Meeting of the Libya Contact Group Chair's Statement' (Istanbul, 15 July 2011) <http://www.mfa. gov.tr/fourth-meeting-of-the-libya-contact-group-chair_s-statement_-15-july-2011_-istanbul.en.mfa> accessed 14 September 2015.

65 UNSC Res 1970 (26 February 2011) UN Doc S/RES/1970, paras 1, 4.

66 See David Bosco, 'Was there Going to be a Benghazi Massacre?' Foreign Affairs (7 April 2011) <http:// foreignpolicy.com/2011/04/07/was-there-going-to-be-a-benghazi-massacre/> accessed 14 September 2015.

67 UNSC Res 1973 (17 March 2011) UN Doc S/RES/1973. 
no immediate threat to civilians, and that by doing so effectively ensured regime change in Libya, because NATO's involvement gave opposition forces the upper hand in the civil war and ultimately enabled them to overthrow the Gaddafi regime. ${ }^{68}$

\subsection{Syria}

A similar story can be told in relation to the international community's engagement with Syria in 2011. In Syria, President Assad was also confronted with mass pro-democracy demonstrations and sought to end these protests through violence and intimidation. As the violence intensified and the human rights situation worsened, members of the international community declared that the Assad regime had lost its legitimacy and could no longer be regarded as the legitimate representative of the Syrian people. For example, the UK, France and Germany issued a joint statement declaring:

Our three countries believe that President Assad, who is resorting to brutal military force against his own people and who is responsible for the situation, has lost all legitimacy and can no longer claim to lead the country. We call on him to face the reality of the complete rejection of his regime by the Syrian people and to step aside in the best interests of Syria and the unity of its people. ${ }^{69}$

Like in Libya, the international community instead accorded legitimacy to the opposition group known as the Syrian Revolutionary and Opposition Forces, or in short the Syrian Opposition Coalition (SOC), on the basis that it was considered representative of the people of Syria and because it had undertaken to guide Syria toward democratic reform. ${ }^{70}$ The government of France announced that: 'it recognizes the Syrian National Coalition as the sole legitimate representative of the Syrian people and thus as the future provisional government of a democratic Syria which paves the way to put an end to Bashar Assad's regime. ${ }^{71}$

Numerous other states quickly followed in recognising the SOC (and thereby contemporaneously de-recognising the Assad regime). The US, for example, referred to the SOC as the "legitimate representative of the Syrian people.. ${ }^{\text {? }}$ Italy declared that

68 See Geir Ulfstein and Hege F Christiansen, 'The Legality of the NATO Bombing in Libya' (2013) 62 ICLQ 159.

69 Quoted in Chris McGreal and Martin Chulov, 'Syria: Assad Must Resign, Says Obama' The Guardian (19 August 2011) <http://www.theguardian.com/world/2011/aug/18/syria-assad-must-resign-obama> accessed 14 September 2015.

70 On recognition of the SOC, see Stefan AG Talmon, 'Recognition of Opposition Groups as the Legitimate Representative of a People' (2013) 12 Chinese JIL 219.

71 French President François Hollande, quoted in 'Reconnait la Coalition Nationale Syrienne' France 24 (13 November 2012, tr by author) <http://www.france24.com/fr/20121113-paris-syrie-hollande-nouvellecoalition-opposition-bachar-al-assad-livraisons-armes-asl> accessed 14 September 2015.

72 US State Department, 'Daily Press Briefing' (13 November 2013) <http://www.state.gov/r/pa/prs/ dpb/2013/11/217517.htm> accessed 14 September 2015. 
'Italy recognizes the coalition as a legitimate representative of the Syrian people." The UK similarly explained that 'Her Majesty's Government has decided to recognise the National Coalition of the Syrian Revolutionary and Opposition Forces as the sole legitimate representative of the Syrian people. ${ }^{74}$ As a collective, the EU recognised the SOC as the legitimate representative of Syria. ${ }^{75}$ Perhaps most importantly, at a meeting of the so-called Group of Friends of the Syrian People, a statement was released on behalf of 'all participants' contributions, ${ }^{76}$ which included 130 state representatives (including approximately 60 ministers), the Syrian opposition and officials from several international and regional organisations and NGOs. This document stated, 'Participants acknowledged the National Coalition as the legitimate representatives of the Syrian People and the umbrella organisation under which the Syrian opposition groups are acting. $^{\text {,77 }}$

In addition to recognising the SOC, various sanctions (including the freezing of assets and travel bans) were imposed by a variety of states and international organisations against members of the Assad regime. ${ }^{78}$ Perhaps more importantly, as the human rights abuses became more severe and a 'red line' was crossed when chemical weapons were used against civilians, members of the international community started to call for military intervention in Syria, as there had been in Libya. ${ }^{79}$ Because of the Russian veto in the Security Council the international community was unable to secure UNauthorised humanitarian intervention in Syria. This notwithstanding, certain members of the international community made it clear that they were prepared to take military action even without UN authorisation in order to alleviate the humanitarian suffering in Syria. Indeed, members of the international community such as the UK and US came extremely close to using military force. ${ }^{80}$ Military intervention was only avoided at the last moment when the British Parliament refused to sanction the government's proposal

73 'Syria: "Coalition is Valid," says Monti' ANSAmed (19 November 2012) <http://www.ansamed.info/ ansamed/en/news/nations/syria/2012/11/19/Syria-coalition-valid-says-Monti_7820520.html> accessed 14 September 2015.

74 HC Deb 20 November 2012, vol 553, col 444.

75 Council of the EU, 'Council Conclusions on Syria' (EU Doc 17515/12, Brussels, 10 December 2012) <http:// register.consilium.europa.eu/doc/srv?l=EN\&f=ST\%2017515\%202012\%20INIT> accessed 28 September 2015.

76 Fourth Ministerial Meeting of the Group of Friends of the Syrian People, 'Chairman's Conclusions' (12 December 2012) <http://www.mofa.go.jp/mofaj/area/syria/friends_kaigo/2012_12/pdfs/2012_12_01.pdf> accessed 14 September 2015.

77 ibid.

78 For an overview of these sanctions, see UK Foreign and Commonwealth Office, 'Embargoes and Sanctions on Syria' (13 August 2012) <https://www.gov.uk/guidance/sanctions-on-syria> accessed 14 September 2015.

79 Glenn Kessler, 'President Obama and the "Red-Line” on Syria's Chemical Weapons' The Washington Post (6 September 2013) <http://www.washingtonpost.com/blogs/fact-checker/wp/2013/09/06/president-obamaand-the-red-line-on-syrias-chemical-weapons/> accessed 14 September 2015.

80 Russell Buchan, 'Syrian Intervention: Legality and Legitimacy' The Times (5 September 2013) <http://www. thetimes.co.uk/tto/law/article3859348.ece> accessed 14 September 2015. 
to use of force, and the Assad regime agreed to the implementation of a stringent regime that enabled an international body to oversee the destruction of Syria's chemical weapons.

It is true that with the rise of the terrorist organisation Islamic State (IS) the conflict in Syria has become more complex. Given that IS is based at least in part in Syrian territory, there has become an urgent need to cooperate with those exercising effective control over territory in Syria (by and large the Assad regime) in order to address the threat to international peace and security that IS represents. But this does not mean that the international community has turned from its commitment to liberal democracy in Syria. The US, for example, has continued to reiterate that, although it must cooperate with the Assad regime out of 'necessity', it continues to be the case that the Assad regime has 'lost legitimacy to govern. ${ }^{82}$ Thus, although practically the exigencies of the situation demand cooperation, normatively the stance of the international community vis-à-vis the Assad regime 'has not changed'. ${ }^{83}$

By way of conclusion, I would suggest that the conduct of the international community since $9 / 11$, and more recently the reaction of the international community to the Arab Spring, lends further support to my claim that there now exists an international community of liberal states that is increasingly dismissing non-liberal states as illegitimate and taking enforcement action against them, seeking to push these states towards liberal reform. Of course there are exceptions and caveats to this explanatory theory, as there is with any such theory. But my claim is that in contrast to the practice of the international society during the Cold War years, where it was agnostic to the form of political governance implemented by its member states, since the end of the Cold War liberal states have consistently engaged in a practice of making normative judgements about the political quality of states on the basis of whether they exhibit respect for liberal values.

\section{Liberal international law}

By definition, all associations comprise individual members that are bound together by a particular normative framework. It is the commitment of these members to this normative framework that provides the association with its sense of collective identity. In order to protect these values the association will necessarily produce and develop

81 'By necessity, there has always been a need for representatives of the Assad regime to be part of this process': US State Department spokeswoman Marie Harf, quoted in 'State Department: Kerry will not Speak to Syrian President Assad' The Guardian (16 March 2015) <http://www.theguardian.com/ world/2015/mar/15/kerry-us-negotiate-bashar-assad-syria> accessed 14 September 2015.

82 John Allen, US Special Envoy to the international coalition against IS, quoted in Nick Tattersall and Stephen Brown, 'US Wants Assad out, Germany Says Talks with Him may be Necessary' Reuters (18 March 2015) <http://www.reuters.com/article/2015/03/18/us-mideast-crisis-syria-usa-idUSKBN0ME1K420150318> accessed 14 September 2015.

83 'General Allen reiterated that the United States position on Assad has not changed': US Embassy in Turkey, quoted in Tattersall and Brown (n 82). 
rules that govern the relations between its members and regulate interaction between members and non-members.

As already noted, the international society is premised upon the principle of the sovereign equality of its member states. In this sense, the principle of sovereign equality can be regarded as a constitutional norm of the international society. ${ }^{84}$ In order to protect this constitutional norm, the international society created concrete international legal rules and, in order to protect these rules, embedded them within international organisations such as the UN. ${ }^{85}$ Vivid illustrations of these legal rules include the principles of non-intervention and the non-use of force.

Although the principle of non-intervention is not expressly included within the UN Charter, it is considered to be the 'corollary' of state sovereignty and 'part and parcel of customary international law' ${ }^{86}$ Turning to the definition of this principle, in the words of the International Court of Justice (ICJ):

Intervention is wrongful when it uses methods of coercion in regard to such choices, which must remain free ones. The element of coercion (...) defines, and indeed forms the very essence of, [a] prohibited intervention. ${ }^{87}$

Coercion is therefore the defining characteristic of intervention. Coercion denotes the imposition of 'imperative pressure', whether it be through military, political or economic means, which manipulates the will of the state, thus compromising or usurping its sovereign authority, in order for the state exercising coercion to realise certain objectives. ${ }^{88}$ It is therefore apparent that it is not possible to define coercion in abstract terms. This is because coercion describes conduct that violates state sovereignty. The concepts of state sovereignty and coercion are thus in a state of mutual dependence whereby our understanding of what matters fall under a state's sovereign authority directly impacts upon what conduct constitutes coercion.

It is for this reason that, at least until the end of the Cold War, the scope of the non-intervention principle was impressively wide. The international society embraced a pristine definition of state sovereignty and for this reason states were considered to possess absolute competence over their domestic affairs. As a result, any dictatorial interference in internal matters was considered to amount to coercion in a state's sovereignty and thus in violation of the principle of non-intervention. As we shall see later in this section, due to the influence of the international community and its redefinition of state sovereignty,

84 According to the International Court of Justice, 'the fundamental principle of State sovereignty [is the basis] on which the whole of international law rests': Military and Paramilitary Activities in and against Nicaragua (Nicaragua v United States of America) (Merits) [1986] ICJ Reports 14 (Nicaragua), 133.

85 Bardo Fassbender, 'The United Nations Charter as Constitution of the International Community' (1998) 36 Columbia J Transnatl L 529.

86 Nicaragua (n 84) 106.

87 ibid 108 .

88 W Michael Reisman, Nullity and Revision: The Review and Enforcement of International Judgments and Awards (Yale UP 1971) 839-40. 
the content of the non-intervention principle has changed dramatically since the end of the Cold War.

The international society also developed the prohibition against the use of force, contained in both article 2(4) UN Charter and also customary international law. The use of force is regarded as a 'particularly obvious' form of intervention which, because of its violent effects on the target state, is considered especially offensive to state sovereignty and therefore deserving of express prohibition. ${ }^{89}$ The prohibition against the use of force extends to conduct that produces 'violence; ${ }^{90}$ that is, the infliction of deprivations upon a state in the form of 'destruction to life and property' through the use of the military or an equivalent instrument. ${ }^{91}$ Note that this prohibition does not only apply to acts of war. This prohibition extends to any use of force which, as just noted, includes any acts producing violent effects. In this sense, article 2(4) is 'intended to be of a comprehensive nature.92

The comprehensive nature of this prohibition is further evidenced by the fact that it applies not only to uses of force but also to threats of force. From the perspective of the international society, a prohibition on threats of force is important because threats of force can be just as damaging as actual uses of force. In addition, threats of force often precede uses of force, as hostilities often escalate. Thus, in order to robustly protect state sovereignty, the international society created a prohibition against the threat or use of force as a means of conflict resolution.

The emergence of the international community has had a profound effect on the content and character of international law. As already explained, the international community is situated within the international society and the regulatory framework that it created. However, whereas the international society is committed to protecting the sovereignty of its member states, the international community possesses an overriding commitment to the promotion of liberal values to non-liberal states. Crucially, the international community seeks to utilise international law to enable and justify its campaign for liberal development. As the influence of the international community has grown, as more states have become liberal, the international community has been able to increasingly adapt existing principles of international law so as to allow for the effective protection and promotion of liberal values.

Consider, for example, the changes to the scope of the non-intervention principle since the end of the Cold War. For the international community, the concept of sovereignty has been redefined. Sovereignty is now defined in terms of responsibility. States are now considered to be subject to an international legal responsibility to protect

89 Nicaragua (n 84) 108.

90 For Dinstein, '[i]t does not matter what specific means-kinetic or electronic-are used to bring it about but the end result must be that violence occurs or is threatened': Yoram Dinstein, War, Aggression and SelfDefence (5th edn, CUP 2011) 88.

91 Ian Brownlie, International Law and the Use of Force by States (Clarendon Press 1963) 362.

92 Bruno Simma, 'NATO, the UN and the Use of Force: Legal Aspects' (1999) 10 EJIL 1, 2. 
the fundamental human rights of their people and where they fail to do this they forfeit their sovereignty. ${ }^{93}$

Given that conduct will only constitute intervention where it impinges upon matters that fall within a state's sovereignty, as the definition of sovereignty has contracted, so has the principle of non-intervention. Thus, since the emergence of the international community there have been suggestions that the practice of liberal states has modified the scope of the non-intervention principle to the extent that it now recognises a human rights exception'; ${ }^{94}$ namely, that states are no longer precluded from intervening in the internal affairs of another state where the objective is to promote respect for human rights. For example, during the Cold War it was well established that where political entities within a state were in the process of determining (whether it be through peaceful or even violent means) who was the government of that state, a state that prematurely recognised an entity as the government committed an unlawful intervention. The principle of non-intervention only permitted states to recognise an entity as the government of a state once that entity had succeeded in exercising effective physical control over the population. ${ }^{95}$ In the contemporary era, however, we witness members of the international community de-recognising incumbent regimes, such as those in Libya and Syria, and instead recognising opposition groups as the legitimate representatives of these states even though they do not exercise effective physical control over the population. Yet, there were few protestations that such conduct constituted a violation of the non-intervention principle, presumably because the Gaddafi and Assad regimes were regarded as having forfeited their sovereignty because of the human rights violations that they perpetrated and because the opposition groups committed themselves to leading these states to a democratic, human rights-respecting future.

Determining under what circumstances intervention is permissible (for example, what types of human rights violation trigger the human rights exception and how severe these abuses must be) and what forms of intervention are acceptable in order to mitigate human rights violations (for example, whether the provision of civilian or even military support and resources to more liberally orientated opposition groups is permissible) requires a careful assessment of state practice. However, this is not the place to engage in a detailed and comprehensive assessment of state practice in order to determine the exact contours of the non-intervention principle. Instead, my argument is that the fact that there is now considerable support for the proposition that the non-intervention principle recognises a human rights exception can be explained on the basis that an intentional community of liberal states has formed within the international society and

93 See, eg, UN Meetings Coverage and Press Releases, 'Secretary-General Presents his Annual Report to General Assembly' (Press Release SG/SM/7136, 20 September 1999) <http://www.un.org/press/ en/1999/19990920.sgsm7136.html> accessed 14 September 2015.

94 Maziar Jamnejad and Michael Wood, 'The Principle of Non-Intervention' (2009) 22 LJIL 345, 376.

95 See Brad Roth, 'Secessions, Coups and the International Rule of Law: Assessing the Decline of the Effective Control Doctrine’ (2010) 11 Melb JIL 1. 
is seeking to redefine existing principles of international law in order to allow for the effective protection of fundamental human rights. ${ }^{96}$

Similar developments have occurred in relation to the non-use of force prohibition. Since the end of the Cold War we have witnessed increasing claims that where a state is unable or unwilling to protect the human rights of its citizens, and where the Security Council is unable to act because of the so-called unreasonable veto, other states can permissibly use armed force in order to alleviate humanitarian suffering-that is, they can use force without committing a violation of article 2(4) UN Charter. ${ }^{97}$ This was the justification of many NATO states when they used force to protect the ethnic Albanians in Kosovo. ${ }^{98}$ More recently, in relation to events in Syria, the UK unambiguously declared that the right to unilateral humanitarian intervention was available under customary international law. ${ }^{99}$ Whether or not humanitarian intervention is a recognised legal basis upon which to use force requires a careful analysis of state practice. Again, this is not the place to engage in such debates. But the point I am making is that the extent to which liberal states are now making such claims is illustrative of the impact of the international community upon the content of international law.

In addition to adapting existing international law principles, the international community has also sought to develop new principles of international law that facilitate the promulgation of liberal values. For example, during the Cold War there was no suggestion that customary international law required states to organise themselves upon a democratic basis. On the contrary, such was the international society's commitment to the sovereign equality of its members that, through the principle of non-intervention, customary international law expressly protected the right of states to determine their own form of political organisation. However, in the years following the end of the Cold War and with the emergence of the international community, it was famously argued by Thomas Franck that the right to democracy was 'emerging' as a principle of customary international law. ${ }^{100}$ As the influence of the international community has increased in recent years, it is now argued that the right to democracy under customary international law is 'undeniable. ${ }^{101}$ I argue that the development of this customary entitlement (or at

96 See Danilo Turk, 'Reflections on Human Rights: Sovereignty of States and the Principle of NonIntervention' in Morten Bergsmo (ed), Human Rights and Criminal Justice for the Downtrodden: Essays in Honour of Asbjom Eide (Martinus Nijhoff 2003) 753.

97 Fernando R Teson, Humanitarian Intervention: An Inquiry into Law and Morality (2nd edn, Transnational 1997).

98 See, eg, the UK's justification in a statement by the UK Secretary of Defence George Robertson, HC Deb, 25 March 1999, vol 328, col 616. For Belgium's justification, see 'Speech by Mr Rusen Ergec, Counsel for Belgium' in Legality of Use of Force (Yugoslavia v Belgium) (Provisional Measures) (ICJ Verbatim Record, CR 1999/15, 10 May 1999) 6.

99 UK Government, 'Policy Paper: Chemical Weapons Use by Syrian Regime: UK Government Legal Position' (29 August 2013) <https://www.gov.uk/government/publications/chemical-weapon-use-by-syrian-regimeuk-government-legal-position/chemical-weapon-use-by-syrian-regime-uk-government-legal-positionhtml-version> accessed 14 September 2015.

100 See generally Franck, 'The Emerging Right to Democratic Governance' (n 28).

101 Theodor Meron, The Humanization of International Law (Martinus Nijhoff 2006) 497. 
least to the extent that it is emerging or developing) can be attributed to the international community.

The emergence of the doctrine of the responsibility to protect (R2P) is also important in this context. In 2001, the Canadian-sponsored International Commission on Intervention and State Sovereignty coined the concept of R2P in order to develop a new framework through which to address humanitarian crises such as those witnessed in Somalia, Rwanda, Bosnia and Kosovo. ${ }^{102}$ The Commission explained that states were under a positive duty to protect the rights of their citizens. Importantly, the Commission suggested that if states failed to perform this duty then the responsibility to protect would pass to the UN. In the first instance, it would pass to the Security Council acting under Chapter VII, but if the Security Council was unable to address the crisis (because of the veto, for example) then the duty must be 'borne by the broader community of states', including regional organisation or even coalitions of states. ${ }^{103}$ In 2005, the General Assembly broadly adopted the position of the Commission, embracing the concept of $\mathrm{R} 2 \mathrm{P}$ and declaring that states are under a positive duty to protect the fundamental human rights of their citizens. ${ }^{104}$ The General Assembly explained that, if a state fails to perform this duty, then the Security Council is entitled to take enforcement action under its Chapter VII powers. Importantly, and in contrast to the Commission's report, the General Assembly did not consider the Security Council to be subject to a positive duty to act; instead, the General Assembly explained that the Security Council had a discretionary power to intervene. Moreover, the General Assembly seemed to reject the idea that if the Security Council were unable to act, the duty to protect would pass to members of the international community more broadly.

It is incontrovertible that the General Assembly watered down the Commission's report and failed to provide an answer to the important question as to how humanitarian crises should be addressed in the face of Security Council paralysis. Stahn therefore contends that the resolution is 'old wine in new bottles. ${ }^{105}$ Although this may be true in substantive terms, this does not mean that the R2P doctrine is without significance. On the contrary, the deployment of the concept of R2P allows for an important conceptual development in international law; namely, that the concept of R2P serves an important rhetorical function in spurring states and international organisations into effectively addressing humanitarian catastrophes. ${ }^{106}$ In a similar vein, the development of the concept of $\mathrm{R} 2 \mathrm{P}$ is being used by the international community as a foundation or catalyst

102 International Commission on Intervention and State Sovereignty, The Responsibility to Protect (2001) $<$ http://responsibilitytoprotect.org/ICISS\%20Report.pdf> accessed 28 September 2015.

103 ibid viii.

1042005 World Summit Outcome, UNGA Res 60/1 (24 October 2005) UN Doc A/RES/60/1, paras 138-39.

105 Carsten Stahn, 'Responsibility to Protect: Political Rhetoric or Emerging Legal Norm?' (2007) 101 AJIL 99, 102.

106 UN Meetings Coverage and Press Releases, “Responsibility to Protect” Came of Age in 2011, SecretaryGeneral Tells Conference, Stressing Need to Prevent Conflict before it Breaks Out' (Press Release SG/SM/14068, 18 January 2012) <http://www.un.org/press/en/2012/sgsm14068.doc.htm> accessed 14 September 2015. 
to generate additional international principles and doctrines that may potentially be used to enable the better protection of fundamental human rights, such as the 'Responsibility to Rebuild'107 and the 'Responsibility to Prosecute. ${ }^{\text {'108 }}$

Although these concepts are in their early stages, even to the extent that they do not constitute international legal rules, I argue that these developments are nevertheless significant and can be explained on the basis of the international community. Stahn recognises that these developments are:

testimony to a broader systemic shift in international law, namely, a growing tendency to recognize that the principle of state sovereignty finds its limits in the protection of 'human security'. Under the concept of responsibility to protect, matters affecting the life of the citizens and subjects of a state are no longer exclusively subject to the discretion of the domestic ruler but are perceived as issues of concern to the broader international community (eg, third states, multilateral institutions, and nonstate actors). This development is part and parcel of a growing transformation of international law from a state and governing-elitebased system of rules into a normative framework designed to protect certain human and community interests. ${ }^{109}$

In its pursuit of liberal reform, the international community has not therefore abandoned international law. As the international community has been able to exercise increasing influence over the world order, the content of the international legal framework constructed by the international society has gradually been modified in order to allow for the promotion of liberal values. In this sense, the will of the international community has emerged as a normative source of international law. This has produced what I call liberal international law.

\section{Conclusion}

This article has defended an explanatory framework that is based upon two coexisting spaces of the international, which I refer to as the international society and the international community. The international society is inclusive of all states regardless of their political identity and is passive in the sense that it seeks to maintain international peace and security by constructing legal rules which prevent intervention in state sovereignty. In contrast, the international community is normatively stronger because it perceives only liberal states to be legitimate, and is future-oriented insofar as it seeks to promote liberal reform to non-liberal states. I argue that it is the interface between these

\footnotetext{
107 James Patterson, 'Jus Post Bellum and the Responsibility to Rebuild' (2014) 45 BJPolS 1.

108 Although the principle of aut dedere aut judicare (the obligation to prosecute or extradite) predates the R2P doctrine, recasting this obligation upon states to prosecute or extradite as a responsibility upon the international community to ensure prosecution is clearly significant: see Jason Ralph and Adrian Gallagher, 'Legitimacy and Faultlines in International Society: The Responsibility to Protect and Prosecute after Libya' (2014) 41 Rev Intl Stud 1.

109 Stahn (n 105) 100-101 (footnotes omitted).
} 
two associations, and in particular the determination of the international community to subject non-liberal states to liberal reform, that can explain why violations of international law and security occur in the contemporary world order.

In this article, I have discussed at length recent examples of the international community engaging in normative judgements of the political quality of states and, where necessary, taking enforcement action against them in order to demonstrate that the doctrine of the international community continues to represent a useful explanatory tool to help explain the nature and character of the contemporary world order. It is important to note that my objective is to explain contemporary events through the doctrine of the international community. I certainly do not attempt to defend (from a normative perspective) the conduct of the international community (for example, whether the international community is correct in its view that liberal states do in fact forge a zone of peace). Clearly, a normative defence of the international community's activities would involve a completely different project. At some point, I may assess the normative desirability of the international community's agenda. But first we must explain why international events occur before they can be understood as a positive or negative development. 